\title{
A methodology for the analysis of communicative interaction in the forums of the Metacampus of the Virtual University System, Universidad de Guadalajara
}

\section{Una metodología para el análisis de la interacción comunicativa en los foros del Metacampus del Sistema de Universidad Virtual, Universidad de Guadalajara}

\author{
MONTES-PONCE, Daniel† \\ Universidad de Guadalajara, Mexico. \\ $1^{\text {st }}$ Author: Daniel, Montes-Ponce / ORC ID: 0000-0003-0905-7364
}

DOI: $10.35429 / J S E M .2020 .21 .7 .13 .28$

Received July 10, 2020; Accepted December 30, 2020

\begin{abstract}
The problem of communication is addressed in a virtual platform, in a communication space: forum, within the platform of the Virtual University System, of the University of Guadalajara, called Metacampus. The objective of the study was: To observe how social life is carried out from the interaction through a virtual medium, in the field of use of information technologies IV. In the methodological work, a mixed paradigm was used, to know what the development of activities is like having as a focus of study: interactive communication, identifying elements of a virtual learning environment. The methodology that was followed to measure the sample was due to the facilities that were presented for being an advisor on the subject of Use of Information Technology, with a sample of 60 students, which results in a representative sample with a level of confidence significant. The results of the analysis of the information worked on the subject Use of Information Technology IV are presented. A significant participation of the participants could be observed, with 590 messages, of which 475 corresponded to students, and 115 from advisers. A trend of Descriptive type messages was identified.
\end{abstract}

Distance education, Communicative interaction, Forum

\section{Resumen}

Se aborda el problema de comunicación en una plataforma virtual, en un espacio de comunicación: foro, dentro de la plataforma del Sistema de Universidad Virtual, de la Universidad de Guadalajara, llamada Metacampus. El objetivo del estudio fue: Observar cómo se lleva a cabo la vida social a partir de la interacción por un medio virtual, en la materia uso de tecnologías de la información IV. En el trabajo metodológico, se utilizó un paradigma mixto, para conocer como es el desarrollo de actividades teniendo como foco de estudio: la comunicación interactiva, identificando elementos de un ambiente virtual de aprendizaje. La metodología que se siguió para la medición de la muestra fue por las facilidades que se presentaron por ser asesor de la materia de Uso de Tecnologías de la Información, con una muestra de 60 estudiantes, lo que resulta una muestra representativa con un nivel de confianza significativo. Se presenta los resultados del análisis de la información trabajada de la materia uso de Tecnologías de la Información IV. Se pudo observar una participación significativa de los participantes, con 590 mensajes, de los cuales 475 correspondieron a estudiantes, y 115 de asesores. Se identificó una tendencia de mensajes de tipo Descriptivos.

Educación a distancia, Interacción comunicativa, Foro

Citation: MONTES-PONCE, Daniel. A methodology for the analysis of communicative interaction in the forums of the Metacampus of the Virtual University System, Universidad de Guadalajara. Journal of Systems and Educational Management. 2020. 7-21:13-28.

$\dagger$ Researcher contributing as first Author. 


\section{Introduction}

Virtual Education, at present, has proved to be a remarkable possibility for training. Entering this type of education will help to strengthen your programs, your instructional design, your practices to the different degrees and programs of the Virtual University System. When analyzing authors like Garcia Aretio (2004), Roquet (2006), Cabero (2009), Moore (2012), and Santander (2012), for example, they affirm that Virtual Education is an evolution of Distance Education, based on digital resources and communication to carry out the teachinglearning process.

Based on this we can say that the different characteristics of Virtual Education are focused on a pedagogical model that promotes through the use of a platform, and technologies the development of activities of students with an interest in improvement and training, updating, specialization, high school, undergraduate or graduate. Thus, in this type of education, a central aspect is the communication, but this being a human practice is an activity of unexpected, inadequate and inconvenient, causing problematic situations, such as scenarios, contexts and problematic circumstances that prevent the communication process is achieved, one of them are the discrepancies and disagreements between participants, and that cause the communication process is not performed for the development of activities within the forum, such as lack of understanding to the activity, technical aspects, formation and teamwork or aspects of instructional design, among others.

This study focused on the practices of interactive communication within LED forums. To analyze interactive communication in the forums, it was necessary to address the aspects of student participation, type of messages, type of interaction and how the work inside the forums is done in the LED's Metacampus platform.

\section{The research problem}

The University of Guadalajara is a public institution that has the social commitment to attend to the education of Jalisco and guarantee the conditions for the formation and updating of the teaching staff and researchers. (UdGVirtual, 2004).
The present work was carried out at the UdeG, in the SUV, which has programs under the Distance Education modality, which are developed on the platform called Metacampus, which implements educational programs at the upper, upper and postgraduate level, one of them is the Bachelor's Degree in Education (LED), which was the one he used to identify the development of activities and the communicative processes carried out in the forum of the subject Use of information technologies IV.

The study focused on circumstances that make the communicative interaction of those involved result in a deficient way, as such is the case of disturbances between those involved, or when the instruction of the activity, technical situations or in another sense the general lack of advice from someone such as an advisor, tutor or technician.

In the same way, the work refers to the importance that ICTs play in communicative interaction in Virtual Education. In this sense, Stacey \& Rice, 2002; Cabero, 2004; Solomon, 2000; Harasim, Hiltz, Turoff \& Teles, 2000; Garrison \& Anderson, (2005), that the communicative interaction offered by ICT is a notable and frequent topic since it facilitates and encourages the intervention of students and advisers through socialization and discussion on virtual platforms facilitating the teachinglearning process.

Based on the above, in the analyzed forums it has been observed that conflictive situations between the advisor and students, or between students, are recurrent in the development of work activities within the forums of the Metacampus platform. This would reveal that the consultant's competencies, in addition to understanding knowledge about the content and material proposed for the job, should reach communication skills to intervene in communication aspects in the forum, as well as to solve complicated situations in their development.

Banzato \& Constantino, (2008), refers to the fact that the role of a virtual advisor has a more complex function in communication than the activity of a face-to-face teacher, which is why he needs training to carry out his advice. 
Thus, the different cases of problematic situations of communication that are presented in a forum, such is the case that the student does not understand the instruction of the activity and asks his peers and advisor and there is no answer, the student enters a situation of desperation to feel alone, and performs the activity in a wrong or deficient way ... this allows then to consider how complex it is to perform in an appropriate manner the communicative interaction in a Virtual Education, as well as virtual training that should have a virtual advisor or tutor.

It is significant to address these elements that are determining factors in the design of a virtual course, but because of my teaching practice within the SUV, through academy meetings, through constant questions from students in the doubts section of the same platform and by email, through the results of evaluation of students of the course before the end of the semester, through informal talks with advisors and students, it is that it has been possible to identify these problem indicators.

Thus, it is necessary to address how the communicative interaction in the LED forums is, and if the activities are based on the application of the principles of the SUV educational model (creative, participatory, meaningful and selfmanagement), as well as to identify how the messages sent to the forums are, and if they affect or promote learning.

\section{The research questions}

Precisely, this research aims to identify elements of interaction between students and advisors in the discussion forums that are part of the teaching-learning process of LED. The research questions posed in the study are:

- How is the interaction in the discussion forums carried out?

- What types of interaction take place in the Metacampus Platform of the Virtual University System?

- What kind of messages are the most frequent in the Metacampus forums?

- In relation to the number of messages sent, how is the participation inside the forums?
When approaching the variety of messages and type of interaction, we can say that the work inside a forum is complex, given the interest, the responsibility and the fulfillment of the instruction of each person is different, that in a way can be satisfied that when sending alone its message with that it fulfills the required thing and obtains its respective evaluation, and within the System of Virtual University of the UDG, it is not known thoroughly as it is this situation, or it is not had documented of formal way.

\section{The object of research}

Based on the above and with the sense of addressing this situation in a practical and real way, the following objective was set for the study:

- To observe how social life is carried out from interaction through a virtual medium, specifically in the use of information technologies IV.

\section{The context}

The work was carried out in the context of the SUV, of the UdeG, which is an institution that carries out research, teaching, extension and linking in the field of knowledge management in virtual environments. The SUV learning model is based on the needs of the learner, considering $\mathrm{him} / \mathrm{her}$ as a person in relation to others, that is, as a subject of community. Any student, even if he or she is enrolled in the program as an individual, has a real school, work, life, professional or power community with which he or she interacts; and his or her education implies that he or she will be perceived in his or her community integration.

\section{Methodological strategy}

A communicative space was approached: the discussion forums, to know how the interaction is and which is the formative value of the discussion forums. The subject of the LED Use of Information Technology IV was chosen because it was the subject to which the LED coordinator facilitated my access, in addition to the fact that in previous semesters I was an advisor on the subject and this allowed me to learn about the program and activities, and for having a special interest in studying and proposing how the work is developed within the forums. 
The mixed methodology allowed me to observe unexpected or routine situations, such as the activities that are carried out in the forum on the Use of Information Technologies IV, where there are processes and activities planned from a certain design and instruction and at the same time it is not known what will happen inside the forum.

The design of the methodology used is based on the type and handling of the information, as well as on answering the research questions and the variables used. In this sense, Driessnack, Sousa, and Costa (2007) refer: "[...] mixed methods refer to a single study that uses multiple or mixed strategies to answer the research questions and/or test hypotheses" (p. 3).

Mixed methodology was used with the aim of obtaining varied and deep information that would allow us to identify the elements that make up the communicative interaction. In this sense, Creswell and Clark (2007) state that researchers have been conducting studies of mixed methods for several decades, since messages and texts were used to analyze, identify, and classify and quantify them according to the number of messages sent by both students and advisors (p. 6-8).

In the same line of thought, Creswell (2008, p. 7) argues that mixed research allows the integration, in the same study, of quantitative and qualitative methodologies, with the purpose of having a greater understanding of the object of study. This aspect, in the case of mixed designs, can be a source of explanation for their emergence and repeated use in sciences that have a direct relationship with social behaviors.

The qualitative methodology allowed identifying general aspects, properties and content of each one of the messages researched. Using variables and categories of research to analyze each of the messages sent to the forum, thus allowing us to know aspects of the reality of how activities are developed within a virtual forum on the Metacampus platform

\section{The design of the research}

The research is descriptive, since it can be used to address and describe what happens in a dialogue in a forum. In this sense, DCA, S. and Acosta V. (2017) refer that descriptive studies can be strengthened by implementing the quantitative methodology because it is more rigorous, and thus increases the reliability

Given my participation within the SUV, the empirical-analytical method or empirical method was implemented by implementing reflection and experience. Therefore, the data and empirical evidence will be obtained from my experience, thus making it possible to reveal the essential relationships and fundamental characteristics of the object of study.

The research was carried out in a natural environment, where we sought to know what happens inside a forum, the participation of those involved, the number of messages and what type of interactions they carry out. Within the approaches that reinforce this approach, the following can be highlighted:

Salgado (2007) states that the design, within the framework of a predominantly qualitative research, is flexible and open, which is why it must be adjusted to the characteristics, not only of the object of study, but also to the conditions in which it is circumscribed.

The present methodological design has elements of the qualitative approach, given the need to address the relational dynamics among the participants: students and advisors, in a forum. In this sense, we can cite what Mertens (2007) refers to, who argues that a fundamental task of the researcher who seeks to understand a complex world is to resort to the analysis of experience from the viewpoint of those who live it and perform it as a way to "[...] understand its various social constructions on the meaning of facts and knowledge" (p. 8).

Likewise, as previously discussed, the results of the studies with mixed design, the authors refer to the fact that they are presented in a triangulated manner, in order to seek consistency among the results of the approaches. 


\section{Procedure}

- Once permission was obtained to enter and observe the work inside the forums, the messages sent by the students to the forum entitled: What is a learning environment? were collected. In order to work on the collection of information, we relied on Creswell (2014) who refers that to collect data in a qualitative research, in this research the type that was used was that of audiovisual materials with the option of computer messages. The author says that the advantages of this type of collection are that it is done discreetly, not directly with the participants, and only analyzes their messages.

- Later, each one of the messages sent to the forum was classified according to the system of selected dimensions, in the sense of mediating the communicative interaction in the forums of the subject, discussion, consenting with it, to observe in a real way the development of activities: messages, works, operations among others.

- Each message was worked on, according to the analysis units selected, where it was possible to identify messages that could be placed in two categories, so we proceeded to code each type of message.

- After that, each one of the messages was quantified and qualified according to the dimensions and units of analysis, in a table to facilitate the handling of the information.

\section{Dimensions}

Bournissen, J. M. (2014) refers that the models for the analysis of virtual teaching and learning have incorporated dimensions related to social, cognitive and metacognitive aspects, where these studies have had diverse approaches.
For the present research, we decided to base our system on the one referred to by Rourke, Anderson, Garrison, and Archer (2005, p. 4) since it better fits the object of study, given that they examine the discourse as the main method, situating the experiences and educational processes, in what they called Community of Inquiry, they affirm that learning happens through interaction in a forum, by means of essential elements that they called: didactic dimension, social dimension, and cognitive dimension.

\section{Didactic Dimension}

In this dimension, the processes of the interaction approach were analyzed and how this should be a determining element for the student to be able to build and develop a meaningful participation where there is debate, formulate and answer questions, which manifest their experiences, that is to say, that the communication process is carried out in a deep way, and in the same way that it is planned, designed and coordinated, which without a doubt should be done by the advisor.

It refers to the critical thinking that Anderson, Garrison and Rurke analyze from an individual perspective, using a comprehensive model, to analyze the practical inquiry, which includes creativity, problem solving, intuition; and on the other hand the advisor, who guides, controls, evaluates, motivates the development of training and activities

To work on this dimension, the indicators and units of analysis proposed by Perera and Torres (2005, p.6), in Table 1, were used and adapted.

In this dimension, analysis units were located, focused on basic elements of the instructional design, such as the course program, its methodology, materials, intervention rules and the messages and respective interventions of the participants. 


\begin{tabular}{|l|l|}
\hline \multicolumn{1}{|c|}{ Analysis unit } & Code \\
\hline $\begin{array}{l}\text { Course program, calendar, contents, activities, } \\
\text { evaluation }\end{array}$ & $\mathrm{RP}$ \\
\hline $\begin{array}{l}\text { Methodology or strategies that guide the } \\
\text { development of activities }\end{array}$ & $\mathrm{DM}$ \\
\hline $\begin{array}{l}\text { Medium and didactic materials necessary for } \\
\text { the development of the course }\end{array}$ & $\mathrm{UMM}$ \\
\hline $\begin{array}{l}\text { Conditions or rules that must be met for the } \\
\text { development of the program }\end{array}$ & $\mathrm{NIR}$ \\
\hline $\begin{array}{l}\text { Advisor or student messages to reach } \\
\text { consensus }\end{array}$ & $\mathrm{ADA}$ \\
\hline $\begin{array}{l}\text { Messages that refer to the parts of the activity } \\
\text { to be carried out to achieve the objective }\end{array}$ & $\mathrm{CAM}$ \\
\hline $\begin{array}{l}\text { Interventions where value judgments are made } \\
\text { on the objective of the activity }\end{array}$ & $\mathrm{ECC}$ \\
\hline
\end{tabular}

Table 1 Didactic Dimension

Source: Own elaboration, taken from the dimensions of Rourke, Anderson, Garrison, and Archer (2005, p.4)

\section{Social dimension}

In this dimension, messages are located where social relationships are fostered, where messages of emotion, congratulations, agreement, among others, are identified. Shin (2002), addresses that communication in a virtual environment requires interaction between teacher and students, to thereby foster a learning community.

The social aspect in the Metacampus forum encourages students to get to know each other, identify who their classmates are, expressing a sense of belonging, not only from the point of view of the task sent to the forum, but also as members of the group, as well as their messages, writing, their collaborations and interaction with their peers.

It allows emotions, desires, interests, needs and criticisms to be expressed, generating exchanges, relationships and a sense of group.

These statements show different aspects that depend on how those involved in the forum participate, hence the name of these variables: dependent, since they depend on the behavior or responses of observable messages of the independent variables, therefore different dependent variables are located in each dimension addressed.

In this sense, Shin (2002) refers that "virtual communication needs interaction between participants, to establish a learning community" (p.121), in Table 2.
In this dimension, units of analysis were located with messages that had a sense of expression of affectivity, and communication and social aspects among the participants.

Analysis unit

Affective messages that express Positive emotions. May include jokes or irony

Messages with intense emotional reactions: criticism

Response - student communication with another student

Response-communication between student and advisor

Number of activities submitted

Table 2 Social Dimension

Source: Own elaboration, taken from the dimensions of Rourke, Anderson, Garrison, and Archer (2005, p.4)

\section{Cognitive dimension}

The development of content on a virtual platform is being implemented at all educational levels, and a space on the platforms are the forums that are increasingly used among teachers in a diverse way, among which they can be mentioned as debate, support to the learning process, socialization of information among others. Our interest in this work is to analyze the formative possibilities of virtual forums in university teaching through collaborative learning strategies. Arango (2003) defines forums as "a setting for communication over the Internet, where debate, agreement and consensus of ideas are encouraged". Based on this, forums make it possible to maintain diverse communication between participants from various places without being in the same place, or at a specific time.

Thus, the cognitive presence, we can affirm that it is information that the participants display information according to a certain instruction.

To analyze this Dimension, indicators and unit of analysis, proposed by Perea and Torres (2005), were approached and adapted. Table 3.

In this dimension, units of analysis related to elements were located where aspects where the student develops knowledge, either individually or in a group, and activity is evidenced in the forum. 
Indicator

\begin{tabular}{|l|l|}
\hline $\begin{array}{l}\text { Identification of } \\
\text { problem }\end{array}$ & $\begin{array}{l}\text { Related message about the } \\
\text { problem. }\end{array}$ \\
\hline Pop-up questions & $\begin{array}{l}\text { Questions that arise during the } \\
\text { development of the topic. }\end{array}$ \\
\hline $\begin{array}{l}\text { Discrepancies with } \\
\text { the group }\end{array}$ & $\begin{array}{l}\text { Oppositions, contradictions } \\
\text { with the group. }\end{array}$ \\
\hline $\begin{array}{l}\text { Change of } \\
\text { information }\end{array}$ & Socialization with the group \\
\hline $\begin{array}{l}\text { Knowledge } \\
\text { appropriation }\end{array}$ & $\begin{array}{l}\text { Information matches with the } \\
\text { group. }\end{array}$ \\
\hline $\begin{array}{l}\text { Accumulation of } \\
\text { ideas }\end{array}$ & $\begin{array}{l}\text { Integration of ideas or } \\
\text { information from various } \\
\text { sources }\end{array}$ \\
\hline Propose solutions & $\begin{array}{l}\text { Implement solution strategy to } \\
\text { solve the problem }\end{array}$ \\
\hline $\begin{array}{l}\text { resolution to the } \\
\text { problem }\end{array}$
\end{tabular}

Table 3 Cognitive Dimension

Source: Own elaboration, taken from Perea and Torres (2005)

\section{Evaluation, or classification of the messages sent}

The evaluation criteria of the messages were worked on when addressing the analysis of the messages in the forums on the educational platform of the diploma, one of the central aspects is the characteristics of each of the messages, and that these when studied allow recognize, differentiate, group and classify the message according to its content.

Given the great variety of topics, perspectives, experiences, convictions, subjects, messages and dedication of the students, this activity is somewhat complicated, since the student generates and participates through this training process, the information is very varied, and to know what the real meaning of the message is, it is necessary to take into consideration rules to be able to carry out a message, which implies that a value judgment can be based on a criterion.

Messages were located that in their content have the disposition or capacity to construct and confirm their meanings, through the discourse of the message that is sent to the forum, that is, with high-level critical thinking, creativity, intuition and problem solving . That the message has approaches exhibiting general knowledge and skills related to the learning process and the topic of the forum. This criterion is more particular and corresponds to the nature of the topic addressed, as well as the level of argumentation that students have in a dialogue, or that they must solve a problem or approach the topic in a coherent and argued way.
It refers to the message expressing opinions or comments that can be refuted, in order to convince other colleagues through proof or reason supported to justify something as true or reasonable. The purpose of the author of the message may be to prove or demonstrate an idea of the content of her message, to refute the contrary or to persuade or dissuade the receiving student about certain content, facts or ideas of the message.

- Interpret, describe meanings of content.

- Classification of messages according to the selected dimension system.

- Quantification of messages in each of the dimensions

This method offered empirical evidence on the reality of the work in the forums, contributing a vision to the structure that the forums have, where you can see the messages if they are analyzed, commented, discussed or if messages are only seen in one species of "chains", Schrire (2006, p. 49), addresses that the term "chain" refers to an exchange of messages within a discussion forum on the internet that refers to the same topic and / or are connected by an interaction implicit or explicit. Or in another sense if the student only sends her activity to the forum, and with this she achieves her participation and respective evaluation, but it is unknown, and there is no documented what the forums produce.

Specifically, the work in the forums, and the messages that are made in it, account for the interactive communication that takes place, and this can be analyzed from different points, by researchers and the teachers or tutors of the students themselves. courses or by those who develop these training experiences. (Rourtke et al., 2005; De Benito and Pérez, 2003; Naidu and Järvellä, 2006).

\section{Sample}

Something significant is that we worked with students with different ages, contexts, experiences, locations, functions in their jobs and homes, with different backgrounds regarding technologies, as well as different ways of thinking. 
The selection process was as follows, the coordinator of the LED was requested to allow us to study the development of activities within the forums of the degree, which provided us with the entrance to the subject of Uses of Technologies and Information IV given the work they do in the forum, and that my participation as an advisor to the LED was known about the program of this matter.

The population of the subject of Use of Information Technology for the fourth semester is 175 students enrolled, and 155 active, in five sections.

The sample used was 60 students, who are enrolled in one section, of which are active participants out of a total of 77 enrolled in two sections, in the area of Use of information technologies IV.

\section{Techniques and instruments for data collection}

When implementing observation, the instruments are mediating elements that transform practices, entities and subjects and have effects on ethnographic practice (Ardevol, Bertrán, Callen \& Pérez, 2006). Virtual environments have included different elements in interpersonal relationships and that is why different elements are required at the same time and / or to adapt the instruments and techniques to be able to study and understand these relationships.

Based on this, the main research instrument used is to be able to enter the field of action and be able to observe the development of activities in relation to: reading, content, participation and manifestations of students in forums .

Also, use information gathering strategies through observation, more specifically through Virtual Ethnography, and by introspection in forums to see how its development is, in addition to the fact that people were not aware that they would be observed during the work in forums, allowed to analyze the activities in a real way, as happens in the natural setting. Thus, the messages-activities were located according to each variable and category, later the information was emptied according to each corresponding instrument.
Likewise, the instruments implemented, refer De Wever et al. (2006, p. 6), must be precise, objective, reliable, replicable and valid. The criteria used in the instruments were directly related to the research categories, where there were difficulties to achieve them, it was a challenge for the research.

Likewise, the instruments implemented, refer De Wever et al. (2006, p. 6), must be precise, objective, reliable, replicable and valid. The criteria used in the instruments were directly related to the research categories, where there were difficulties to achieve them, it was a challenge for the research.

\section{Evaluation criteria of the information obtained}

The indicators on which we base ourselves to evaluate the messages on the subject of Use of Information Technology IV are the following:

Participation with the date of when the forum opens, number of participations for the time the forum is enabled, originality of the message, contribution of complementary information, with definition, with citations, as well as the application of knowledge, relevance, prioritization of the main knowledge, justification, breadth of knowledge, new ideas, solutions or conclusions, use of social or emotional signals.

Based on the above, each of the 590 messages sent by students and advisers to the Metacampus forums on the subject Use of Information Technology IV was classified. The classification was carried out manually, analyzing, filling in the data collection instrument. Likewise, the MaxQDA program was used to correlate messages with association of variables. The program gave them a certain percentage to a classification nomenclature as follows: analytical, descriptive, dependent and autonomous. Which can be defined as follows:

- Analytical message. This message in its content must show that for its development it implied the analysis and decomposition of the subject, that is, the separation of a whole into its parts or its constituent elements. 
It requires full mastery of the topic, for this the student definitely needs the preparation of it, through the previous materials, this will evidence the mastery of the topic and that it is according to the reading and requested topic, which allows its content is according to the nature of the topic and the object to be developed.

- Descriptive message. Message that refers to the characteristics or properties of the topic addressed, where to describe the topic then supposes a form of analysis, since it implies the decomposition of its object into parts or elements and the attribution of properties or qualities, describing its entire aspect .

- Dependent message. It is a message that is not authentic and does not have the privilege of being totally independent from other messages. That is, it is in function and at the expense of the characteristics of another or other messages, in it you can find words such as: "it says ...", "I agree with what it mentions ...", "I think the same as ...".

- Autonomous message. It is a message that does not depend on other messages for its content, it enjoys autonomy; its content is independently, without being subordinate to another message. Your content is authentic personal and can be free from the main topic of the forum work.

These areas of analysis, with the established indicators and criteria, provide the basis for framing the following categories to be implemented in the analysis of the messages of the Metacampus forums: pertinent, elementary and deficient. Of which they can be identified as follows:

- Relevant. When the message is related or belongs to the topic addressed, in a sufficient, appropriate and timely manner. It gathers the quality, structure and correct and efficient foundation, responds and responds to the solution in question, or to the need of what is addressed, so it is necessary to be appropriate and viable.

- Elementary. When the message is basic, simple and easy to perceive, also when it meets the minimum characteristics to be understood.
- Poor. When the message lacks quality, content and relevance, that is, it is incomplete, and does not meet the minimum characteristics to be understood and can resolve or respond to the issue, it can be said that it is insufficient, scarce and not enough exact or necessary to make a process that contributes and concludes.

\section{Results}

The analysis of the information collected was an interesting activity, because despite having such varied information on participations, content and types of messages, it was an enriching activity when seeing the percentages of interventions in the forums of the subject Use of Information technologies IV, as well as their relationship with the object of study, that is: to observe how social life is carried out from interaction through a virtual medium; and identify and interpret the reality of what is happening in the Metacampus discussion forums.

Performing the analysis of the information obtained, from the didactic, social and cognitive dimensions, allowed to analyze and classify the types of messages identified, such as: analytical, dependent and descriptive, and according to the established categories such as: pertinent, elementary, deficient and absent, it allowed to establish results to know how is the interaction between the participants in the forum space.

The analysis of the information is presented, in which a significant participation could be identified, with a total of 590 messages, of which 475 corresponded to students, while 115 were from advisers, identifying a scarce and deficient participantion. See Table 4.

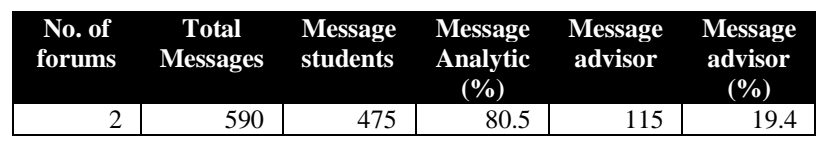

Table 4 Analysis of general information on the subject: Use of Information Technologies IV. Subject: Use of Information Technologies IV

Source: Self made 
A greater number of descriptive messages could be observed, since the vast majority of these only send their activity narrating and relating content in a general way, which aims to define the topic requested by the activity instruction, according to their vision of the reality of what it represents in an impersonal way, addressing the features that best suit the author of the message.

The total of descriptive messages sent in this matter was 253, giving $42.88 \%$, and with respect to its relationship with the object of study that the program threw, it is that it saves $85 \%$; Therefore, the category given to these messages was pertinent, given that they are related or belong to the topic addressed in the activity, in a sufficient, adequate and timely manner. In this matter there were two forums, in one there were 108 and in the second of 145 messages, respectively.

In the case of dependent messages, they could be located according to the established criteria, that they are not authentic messages, their own, that is, they do not have content or characteristics independent of the other messages that their colleagues sent to the forum, It can be said that it does not contribute anything new and significant to the development of the activity. Messages were found such as: "I agree with...", "I think the same as...".

Later, the type of messages that continued in relation to the number was that of analytical messages, with a total of 126 , which were classified based on their content, where it can be deduced that their work involved analysis and decomposition of the subject, that is, the separation of a whole into its parts or its constituent elements.

Otherwise, the autonomous messages were located according to the content that is authentic and is not a copy or like another that has been sent to the forum. Based on this, 23 messages could be located, with a category of deficient due to incomplete, deficient content. In the forum one was located 8 , and in the two 15 messages. See Table 5.
We were able to verify a difference in the types of messages by students and advisor in this matter, which reflects a proportion of descriptive messages with 253. These results in the table show a very poor participation of the advisor, minimal, with only 115 messages out of a total of 590. This gives us a percentage of $19.4 \%$ and an average of 5.1, which goes against the importance of this factor for the student to participate in the forum, since one or the other In this way, the messages prepared by the consultant should motivate and drive their intervention.

Contrary to this, if we compare the student's participation, it was very different, with 475 messages, which gives us a percentage of $80.5 \%$ and an average of 7.9 , which reflects a very large difference, which occurs according to the matter. See table 6.

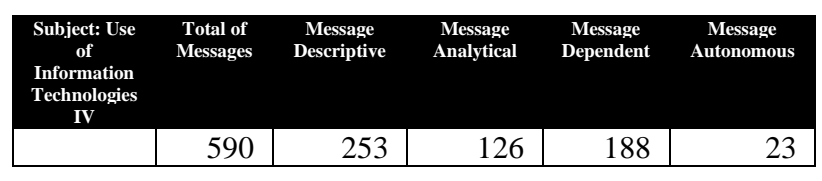

Table 5 Type of messages: Use of Information Technologies IV

Source: Own elaboration

Likewise, it was possible to observe a marked difference in the work in each forum, in one there were a total of 245 messages, while in two there were 345 . In relation to the classification in categories, differences could be noted; this could also be verified regarding the type of message. In the descriptive forum in one there were 108 with a relevant category, while in two there was an increase, there were 145 . The dependent messages were a total of 90 messages, with a category of elementary; while in two a small increase was also observed with 98. And within the most significant, analytical messages followed, with 39 and 87 messages, for forums one and two respectively, to which the program gave a category of poor.

It was possible to show that the greatest weight of messages was in forum two and the type of descriptive messages with a relevant category, but it should be noted that for the other messages a constant was the messages with a deficient category. 
Therefore, it can be said that in this matter the relevant messages had greater weight with 253 messages, followed by those of the Dependent, Analytical and finally SelfEmployed types, also showing greater participation in forum two: This can be put in table 6.

\begin{tabular}{|l|r|r|l|r|r|}
\hline \multicolumn{6}{|c|}{ Subject: uses of information technologies iv. 590 messages } \\
\hline Message & Total & $\%$ & Category & $\begin{array}{l}\text { Forum } \\
1\end{array}$ & $\begin{array}{l}\text { Forum } \\
2\end{array}$ \\
\hline Analytical & 126 & 21.35 & Deficient & 39 & 87 \\
\hline Descriptive & 253 & 42.88 & Relevant & 108 & 145 \\
\hline Dependent & 188 & 31.86 & Elementary & 90 & 98 \\
\hline Autonomous & 23 & 3.8 & Deficient & 8 & 15 \\
\hline Total Posts: & \multicolumn{7}{|c|}{590} & 245 & 345 \\
\hline
\end{tabular}

Table 6 Results by categories, subject: Use of Information Technology IV

Source: Self made

In Graphic 1, a noticeable difference is observed in the types of messages located in the forum of the subject of Use of Information Technology IV, the descriptive messages are those that were observed in their majority with 253 and $42.88 \%$, while that the messages that were observed in less quantity were the autonomous type, with 23 , and a percentage of $3.8 \%$.

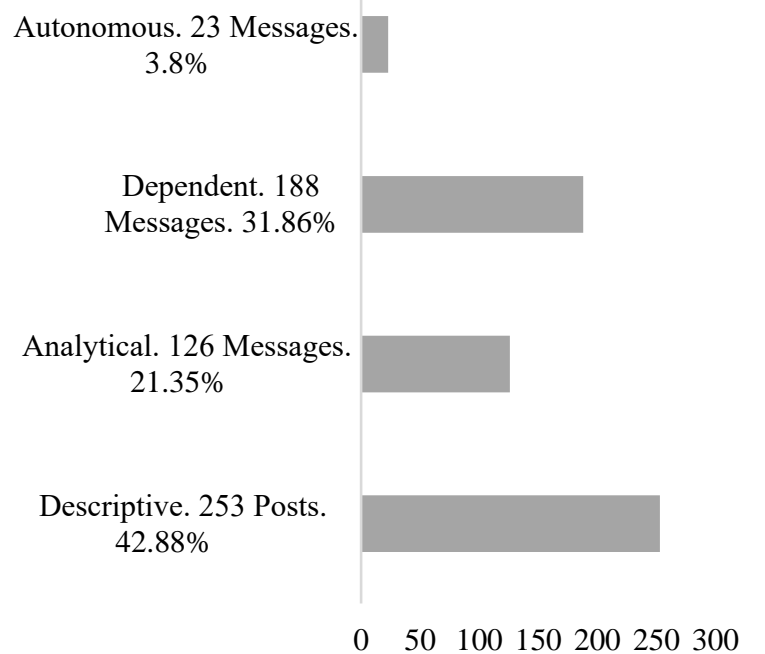

Graphic 1 Percentages: Uses of Information Technology IV. 590 Posts

Elaboration: Own

\section{Conclusions}

Based on the results obtained, it can be affirmed that the forums fulfill their function, that is, that an educational communication is carried out, with the execution of a design that offers an instruction, and the students implement it through an activity of a or other way.
With this, it can be concluded that:

- That the activities in the forum created in the respective matter, a communicative interaction was carried out between the participants, for which they sent their activity according to a specific instruction, observing delivery, disposition and understanding of the requested topic, in 590 messages sent.

- That the communicative interaction takes place between advisers and students, because diverse messages could be identified, such as descriptive, analytical, dependent and autonomous, whether academic and social.

- It can be affirmed that the communicative interaction was revealing, because according to what was analyzed based on the social dimension, messages that focus entirely on social relationships were classified, the participants interact continuously where emotions, gratitude are expressed, congratulations, that is messages with a playful and motivational content.

- A large participation was observed with 590 messages, where the descriptive message was the one that had a greater participation with 253 and $42.88 \%$, where the program gave it a category of relevant because its content is directly related to a Sufficient and appropriate way to what the instruction marks, of the topic to be developed, while the messages that were observed in less quantity were the autonomous type, with 23 , and a percentage of $3.8 \%$.

- Something that is significant to conclude is that the development of work within the forum is merely personal, with a limited communicative interaction of an academic nature, where collaborative learning can be promoted, because no debate, questioning or being in agreement for the content of the topic addressed. It could be observed that the vast majority were social messages, that is, motivational, affective or congratulatory.

- The participation of the responsible advisor was scarce, where the students interact constantly with each other, and the advisor participates poorly and answers in blocks, observing little individual feedback. 
- Forums become a space for displaying messages, where academic development was not observed, the content of the message is not regularly analyzed, nor is there discussion, criticism or improvements to the activity are not proposed.

Regarding the research questions, the following can be stated:

- How is interaction carried out in the discussion forums?

It can be affirmed that it is significant, since according to the social dimension, the work in the forums could be observed messages in which the students show social relationships, interact and promote dynamics where emotions, congratulations, thanks, contributions are expressed playful, jokes, greetings, ask questions, and refer to the group as a we, which would imply their cohesion motivations show that they are united by the same goal, that is, sharing knowledge.

Thus, these interactions, observed and analyzed, it can be concluded that they lead to establish a certain empathy between the participants, and in a certain way provoke a special interest of the advisor in the student's process, which results in a personalized orientation adapted to their needs and processes.

Based on the above, the results obtained, the dimensions and the categories worked, it can be stated that communicative interaction takes place in the forums, according to:

First, since asynchronous activities are carried out in the forum, students participate in the forum without waiting time and day to enter, so they can send contributions during the period that the forum is enabled.

The second is that the functionality of the forums is that communicative interaction is carried out, as an action in which students participate in one way or another, whether social or academic, implementing a dialogic context where discussion is generated that contributes to the topic.

- What types of interaction are carried out in the forum of the subject of Use of Technologies IV?
According to what was observed, and the quantification of messages sent with a total of 590 , and when carrying out an analysis of the messages with the dimensions addressed, it was possible to relate and affirm that the interactions found are located with those proposed by Hirumi (2002):

I. The apprentice alone, with himself

II. The apprentice with human resources:

- Trainee-instructor.

- Apprentice-apprentice.

- Apprentice-with other participants.

III. The apprentice-instruction:

- Learner-contents.

- Learner- interface.

- Learner-environment.

Based on the above, the main contribution to the Metacampus was that the forum space is a real communicative interaction, where students participate in one way or another promoting learning both individually and collaboratively. With the present study, it was possible to observe that social life within forums is an indispensable tool for interaction to take place through a virtual medium.

\section{References}

Anderson, T. (2010). Interactions Affording Distance Science Education. In D. Kennepohl \& L. Shaw (Eds.), Accessible Elements: Teaching Science Online and at a Distance (pp. 1-18). Edmonton: Athabasca University Press. Retrieved from http://www.aupress.ca/books/120162/ebook/01

_Kennepohl_Shaw_2010Accessible_Elements.pdf

Anderson, T. D. \& Archer, W. (2000). Social presence in computer conferencing: Chewing the phat(ic). Unpublished paper. 
Arango, M. (2003). Foros virtuales como estrategia de aprendizaje. En revista Debates latinoamericano, (2). Recuperado de http://www.rlcu.org.ar/ revista/numeros/02-02Abril-2004/documentos/Arango.pdf

Ardevol, E., Bertrán, M., Callen, B., Pérez, C. (2003). Etnografía virtualizada: la observación participante y la entrevista semiestructurada en línea. Universitat Oberta de Catalunya, Barcelona.

Babbie, E. (2000). Fundamentos de la investigación social. México, D. F.: Internacional Thompson Editores.

Bates, A.W. (2001). Conferencia: Aspectos culturales y éticos en la educación internacional a distancia.

(2001). Cómo gestionar el cambio tecnológico. Estrategias para los responsables de centros universitarios (Ediuoc-Gedisa). Avance Editorial del Libro.

Bates, T. (1995). Technology, open learning and distance education. Londres, Inglaterra: Coldeway, D., 1982. A

(1999). Managing technological change: Strategies for college and university leaders. San Francisco: Jossey Bass.

Bustamante, R. H. (2008). Los enredos de la afectividad con Internet. Boletín SUAyEd, tomo 3, UNAM.

Cabero, J. y Llorente, M. C. (2010). Comunidades virtuales para el aprendizaje. EDUTEC, Revista Electrónica de Tecnología Educativa. Núm. 34 /diciembre 2010. Recuperado

http://edutec.rediris.es/revelec2/revelec34/

Cabero, J., Llorente, C. \& Puentes, A. (2010). La satisfacción en los estudiantes en red en la formación semipresencial. Revista científica de educomunicación. Comunicar, 35 (XVIII), pp. 149-157. Recuperado de http://www.scielo.org.co/pdf/rlcs/v10n1/v10n1a 09
Cabero, J. (2009). Los nuevos escenarios y las nuevas modalidades de formación: Las aportaciones desde las nuevas y antiguas tecnologías. En J. Tejada y otros (coord.), IV Congreso de formación para el trabajo (187207). Madrid: Tornapunta Ediciones.

. (2004). Las TICs como elementos para la flexibilización de los espacios educativos: retos y preocupaciones. En Comunicación Y Pedagogía. No 194, 13-19. ISSN: 1136-7733.

Cea, M. Á. (2001). Metodología cuantitativa. Estrategias y técnicas de investigación social. ( $3^{a}$ Reimpresión). Madrid, España: Editorial Síntesis.

Creswell, J. W. (2008). Educational research: Planning, conducting, and evaluating Creswell, J. W. \& Plano Clark, V. L. (2007). Designing and conductingMixed Methods research. Thousand Oaks, CA: Sage. Doi: $10.1177 / 1558689807306132$

De Benito, B. \& Pérez, A. (2003). La evaluación de los aprendizajes en entornos de aprendizaje cooperativos. En Martínez, F. Redes de comunicación en la enseñanza: Las nuevas perspectivas del trabajo corporativo, pp 209- 226 Barcelona, Buenos Aires, México: Paidós

De Wever, B., Schellens, T., Valcke, M. \& VanKeer H. (2006). Content analysis schemes to analyze transcripts of online asynchronous discussion groups: A review, Computers \& Education, 46, 6-28.

Díaz Barriga, F. \& Hernández, G. (2002). Estrategias docentes para un aprendizaje significativo. Una interpretación constructivista. $2^{\mathrm{a}}$. ed. México, D. F., México: McGraw-Hill.

Driessnack, M., Sousa, V. y Costa, I. (setiembreoctubre, 2007). Revisión de los diseños de investigación relevantes para la enfermería: parte 3: métodos mixtos y múltiples. Revista Latino-americana de Enfermagem, 15(5), 179182. Recuperado de http://www.scielo.br/pdf/rlae/v15n5/es_v15n5a 24.pdf

Feasley, C. (1983). Serving learners at a distance: A guide to program practices. ASHEERIC Higher Education Research Report No. 5. Washington, DC, EE. UU.: Association for the Study of Higher Education. 
García, J. (2005). Panorama evolutivo de la educación a distancia. Contextoeducativo.com.ar/ 2005/3/nota-08.htm-41k. Recuperado de http://www.educrea.cl/documentacion/

articulos/educacion_a_distancia/02_panorama _evolutivo_educacion_distancia.html

GarcíaAretio, L. (2004). Viejos y nuevos modelos de educación a distancia. Bordón. Vol. 56. pp. 409-429.

García, C. y Perea, V. (2007). Comunicación y aprendizaje electrónico: la interacción didáctica en los nuevos espacios virtuales de aprendizaje. Revista de Educación, 343. Recuperado de http://www.revistaeducacion.mec.es/re343/re34 3_17.pdf

Garrison, D. R. \& Anderson, T. (2005). El elearning en el siglo XXI. Barcelona. Octaedro.

Garrison, D. R., Anderson, T. \& Archer, W. (2000). Critical inquiry in a text-based environment: Computer conferencing in higher education. The Internet and HigherEducation, 2(2-3), 87-105.

Gil, J. \& Perera, V. (2001). Análisis informatizado de datos cualitativos. Sevilla: Kronos.

Goetz, J. y Le Compte, M. (1988). Etnografía y diseño cualitativo en investigación educativa. Madrid: Morata.

Gros, B. \& Silva, J. (2006). El problema del análisis de las discusiones asincrónicas en el aprendizaje colaborativo mediado. RED. Revista de Educación a Distancia, 16. Recuperado de http://www.um.es/ead/red/16

Gunawardena, C. N., Lowe, C. A. \& Anderson, T. (1997). Analysis of a global online debate and the development of an interaction analysis model for examining social construction of knowledge in computer conferencing. Journal of Educational Computing Research, 17(4), 397431.

Gutiérrez, A. (2005). La comunicación didáctica en los espacios electrónicos de aprendizaje de la educación a distancia. México. Recuperado de http://www.crefal.edu.mx/biblioteca_digital/CE DEAL/acervo_digital/coleccion_crefal/cuadern os_estancias/alma_elena/indice.htm
Harasim, L., Hiltz, S. R., Turoff, M. y Teles, L. (2000). Redes de aprendizaje. Guía para la enseñanza y el aprendizaje en red. Barcelona: Gedisa.

Henri, F. (1992). Computer conferencing and content analysis. En A.R.

Hernández, R. (1998). Calidad-formatividad del estudiante universitario. Memorias del XII Encuentro Nacional de Investigación Educativa. Instituto Michoacano de Ciencias de la Educación "José María Morelos". Morelia, Mich., México. 19, 20 y 21 de noviembre de 1998.

Hernández, R., Fernández, C. y Baptista, P. (2003). Metodología de la investigación ( $3^{\mathrm{a}} \mathrm{ed}$.). México: Editorial Mc Graw-Hill.

Hirumi, A. (2002). The design and sequencing of learning interactions: a grounded approach. Material del curso "Las interacciones en entornos virtuales y sus estándares de calidad (eLearning)", organizado por la Universidad de Guadalajara del 27 al 29 de noviembre.

Hirumi, A. (1997). Systematic strategies for promoting interactivity and student-centered learning at a distance. Memorias del taller de Educación a Distancia (Distance Education Workshop). México.

Hmelo-Silver, C. (2003). Analyzing collaborative knowledge construction multiple methods for integrated understanding, Computers \& Education, 41(4), 397-420

Kearsley, G. (1997). Constructivist theory. Recuperado de http://www.gwu.edu/ -tip/bruner.html

- (1997a). Social development theory. Recuperado de http://www.gwu.edu/ $\sim$ tip/vygotsky.html

(s. f.). The theory into practice database. Recuperado de http://tip.psychology.org/ gagne.html

Le Compte, M. y Schensul, J. (1999). Designing and Conducting Ethographic Research [Diseño y realización de investigación etnográfica]. London: AltaMira Press. 
Marcelo, C. y Perera, V. H. (2004). El análisis de la interacción didáctica en los nuevos ambientes de aprendizaje virtual. Revista Bordón, vol. 56, nº. 4. pp. 7095.

Mertens, D. (2007). Transformative Paradigm Mixed Methods and Social Justice [Paradigma transformativo metodos mixtos y justicia social]. Journal of Mixed Methods Research, 1(3), 212225. doi: 10.1177/1558689807302811

Moore, M. G. (2012). The theory of transactional distance. In M. G. Moore (Ed.) (2012) The Handbook of Distance Education. Third Edition. New York, Routledge. pp. 131170.

Moore, M. G. \& Kearsley, G. (2005). Distance education: A system view ( ${ }^{\text {a }}$. ed.). Belmont, CA, EE. UU.: Wadsworth Publishing.

-. (1996). Distance education: A systems view. Belmont, CA: Wadsworth Publishing Company. Recuperado de http://biblioteca.itson.mx/oal formacion_profesores/oa2/analisis_destinatari os/ad2.htm

Moore, M. G. (1989). Three types of interaction. The American Journal of Distance Education, 3(2), 1-6. Recuperado de http://dx.doi.org/10.1080/08923648909526659 170

Moreno, M. (2012). Informe de actividades. Guadalajara, Jalisco. Mex: Sistema de Universidad Virtual, Universidad de Guadalajara.

Naidu, S. \& Jarvela, S. (2006). Analyzing CMC content for what? Computers \& Education, 46, 96-103.

Olavarria, G. (2004). Educación a distancia y universidades. La experiencia de la GDLN1. Distance Learning and Universities. The case of GDLN. Instituto de Asuntos Públicos, Universidad. RED. Revista de Educación a Distancia. Recuperado de: http://www.um.es/ead/red/16/olavarria.pdf

PadulaJ. E. (2003). Una Introducción a la Educación a Distancia Argentina Fondo de Cultura Económica. pp 91.
Padula, J. E., (2004). Generalidades y Particularidades de la Educación a Distancia". "Difundiendo la Educación a Distancia" Cinterac Capacitación a Distancia, Buenos Aires. Recuperado de http://www.edudistacom/index.htm

Perera, V. y Torres J. J. (2005). Análisis de las condiciones pedagógicas, sociales y cognitivas en los foros de discusión online. Recuperado de http://prometeo.us.es/idea/publicaciones/hugo/ 10.pdf

Puntambekar, S. \& Hübscher, R. (2005). Tools for scaffolding students in a complex environment: What have we gained and what have we missed? Educational Psychologist. 40 (1).

Pungambekar, S. \& Luckin, R. (2003) Documenting collaborative learning: what should be measured and how? Computers \& Education, 41, 309-311.

Rafaeli, S. \& Ariel, Y. (2007). Assessing Interactivity in Computer-Mediated Research, in Joinson, A.N., McKenna, K.Y.A., Postmes, T. and Rieps, U.D. (Eds.) The Oxford Handbook of Internet Psychology, Oxford University Press, (Chapter 6, pp. 71-88) 2007.

Rebollo, Ma A. (2001). Discurso y educación. Sevilla: Mergablum.

Radrigan R. (2005). Metodología de la Investigación.

Rodríguez, G., Gómez, J. y Gil, J. (1996). Métodos de la investigación cualitativa. Málaga, España: Ediciones ALJIBE.

Roquet, G. (2006). Antecedentes históricos de la Educación a distancia. Coordinación de Universidad Abierta y Educación a Distancia. Universidad Nacional Autónoma de México. Recuperado de http://www.academia.edu/8634122/UNIVERSI DAD_NACIONAL_AUT\%C3\%93NOMA_DE_ M\%C3\%89XICO_Antecedentes_hist\%C3\%B3r icos_de_la_Educaci\%C3\%B3n_a_distancia_M \%C3\%A9xico_Versi\%C3\%B3n_2006_Anteced entes_hist \%C3\%B3ricos_de_la_Educaci\%C3\% $B 3 n \_a \_d i s t a n c i a$ 
Rourke, L. Anderson, T. Garrison D. R. \& Archer, W. (2005). Cuestiones metológicas relativas al análisis de contenidos de las transcripciones de clases por ordenador. En Garrison, D.R y Anderson, T. (2003), El e-learning en el siglo XXI: Investigación y práctica, pp 175- 202 Barcelona:Octaedro, (Versión original: E-learning in the 21 st century, RoutledgeFalmer, 2003).

Rusque, A. (2007). De la diversidad a la unidad en la investigación cualitativa. Vadell Hermanos Editores, Caracas

Salgado, A. (setiembre, 2007). Investigación cualitativa: diseños, evaluación del rigor metodológico y retos. LIBERABIT, 13, 71-78. Recuperado de www.scielo.org.pe/pdf/liber/v13n13/a09v13n13 .$p d f$

Salomon, G. (2000). E-moderating: The key to teaching and learning online, London: Kogan Page.

Santander, W. (2012). Una Visión del Estado del Arte en la Educación Superior a Distancia en Chile. XIII Encuentro Internacional Virtual Educa - PANAMA 2012.

Schrire, S. (2006). Knowledge building in asynchronous discussion groups: Going beyond quantitative analysis, Computers \& Education, $46,49-70$

Shin, N. (2002). Beyond interaction: the relational construct of Transactional $\mathrm{MN}$ Presence, In Open Learning, 17(2), 121-137.

Silva, J. E. (2007). Las interacciones en un entorno virtual de aprendizaje para la formación continua de docentes de enseñanza básica. Tesis de doctorado para obtener el título de Doctor en Multimedia Educativo, Facultad en Ciencias de la Educación, Universidad de Barcelona. Recuperado http://www.tesisenxarxa.net/TDX-0713107120211/index.html

Smolka, A. (1996). Voices of discourse: someconceptions in issues in psychologicalstudies, in II Conference of Sociocultural Research, Ginebra (documento policopiado).
Stacey, E. \& Rice, N. (2002). Evaluating an online learning environment. Australian Journal of Educational Technology, 18(3), 323-340.

UdGVirtual (2004). Modelo académico del Sistema de Universidad Virtual. Recuperado de www.udgvirtual.udg. $\mathrm{mx} /$ gestorB/categoria/sho w_archivo.php?id=111

Universidad de Guadalajara. (2014). Licenciatura en Educación. Disponible en: Universidad de Guadalajara (1992). Dictamen de creación de la División de Educación Abierta y a Distancia del Consejo General Universitario, noviembre de 1992.

Valcke, M. \& Martens, R. (2006). The problem arena of researching computer supported collaborative learning: Introduction to the special section, Computers \& Education, 46, 15

Wallace, R. M. (2003). Online Learning in Higher Education: a review of research oninteractions among teachers and students», en Education, Communication \&Information, 3(2), 241-280.

Yacci, M. (2000). Interactivity Demystified: A Structural Definition for Distance Education and Intelligent CBT. Recuperado de http://www.it.rit.edu/ may/interactiv8.pdf 